\title{
A GENERATÍV TERVEZÉST TÁMOGATÓ SZOFTVEREK RÖVID ÁTTEKINTÉSE
}

\author{
Szabó Kristóf \\ PhD hallgató, Miskolci Egyetem, Szerszámgépek Intézeti Tanszéke \\ 3515 Miskolc, Miskolc-Egyetemváros,e-mail: szabo.kristof@uni-miskolc.hu \\ Hegedüs György \\ egyetemi docens, Miskolci Egyetem, Szerszámgépek Intézeti Tanszéke \\ 3515 Miskolc, Miskolc-Egyetemváros, e-mail: hegedus.gyorgy@uni-miskolc.hu
}

\begin{abstract}
Absztrakt
Az elmúlt években megjelent új generatív tervezési folyamat egyre több szoftverben vált elérhetövé. A klasszikus gyors-prototípus készitési eljárásokkal a megtervezett termékek tartós müködés közbeni vizsgálatára nem volt lehetöség. A fémporos nyomtatás és az additív technológia megjelenése azonban már lehetövé teszi a megtervezett prototípusok tartós vizsgálatát, söt, ha a termék elört tulajdonságaitól csak elhanyagolható mértékü az eltérés, akkor a végleges termékek elöállitását is. Ennek következtében a generativ tervezési folyamattal eddig elképzelhetetlennek tünt termékek létrehozására is lehetösége van a tervezömérnököknek.
\end{abstract}

Kulcsszavak: alakoptimalizálás, topológiai optimalizálás, generativ tervezés

\begin{abstract}
The new generative design process that has emerged in recent years has become available in more and more software. With the classic rapid prototyping procedures, it was not possible to test the designed products during long-term operation. However, the advent of metal powder printing and additive technology already allows for the long-term testing of designed prototypes, and even, if the deviation from the required properties of the product is negligible, the production of the final products. As a result, with the generative design process, design engineers also have the opportunity to create products that seemed unthinkable so far.
\end{abstract}

Keywords: shape optimisation, topology optimisation, generative design

\section{Bevezetés}

Egy termék alakját elsősorban a termékkel megvalósítandó funkciók határozzák meg, amit kismértékben befolyásolhatnak a termék gyártástechnológiai tulajdonságai (pl. forgácsolt vagy öntött alkatrészek). A hagyományos alkatrészeken - eltekintve a szabadformájú felületektől - a legtöbbször síkokkal vagy hengeres felületekkel határolt burkolófelületekkel találkozunk. Egy adott termék fejlesztése során különböző mérnöki vizsgálatokat célszerü végrehajtani, majd az eredményeket elemezve a terméket javítani. Ez lehet a termék tömegének csökkentése, a termék terhelhetőségének növelése, vagy végleges geometriájának módosítása. Ez az iteratív tervezési-fejlesztési folyamat tekinthető egy optimális megoldás keresésének is, azonban ez a folyamat időigényes és sok tapasztalatot igényel. Ha egy termék fejlesztésekor a hagyományos gyártástechnológiai müveleteket (pl. prizmatikus marás) is figyelembe vesszük, belátható, hogy lehetnek olyan megoldásaink is, 
melyeknek a gyártástechnológia szab határt. A számítógépes tervezőrendszerek CAD/CAM moduljai, vagy az egyedi $\mathrm{CAD}$ és CAM szoftverek többségében olyan modellező eljárásokat, vagy gyártástechnológiai folyamatokat támogatnak, amelyek a hagyományos tervezési szemléletnek felelnek meg. Ez a gyakorlatban az alaksajátosságalapú, parametrikus modellezést jelenti a CAD oldalon és az anyageltávolítással (szubsztraktív) járó megmunkálást (pl. marás, esztergálás) a CAM müveleteknél. A szoftverekben található alakoptimalizálást biztosító beépített algoritmusokat a hagyományos tervezési szemlélet korlátainak megfelelően alakították ki. Az additív megmunkálási technológia alkalmazásával azonban olyan termékek is elöállíthatók, melyeket korábban megmunkálhatatlannak képzeltünk (pl. hozzáférhetetlen felületek, „bennszülött” elemek). Megjegyezzük, hogy az additív megmunkálás egy gyüjtőfogalom, ide sorolhatók a régóta ismert gyors-prototípusgyártási eljárások is, amelyek nagyrészt polimer alapanyaggal dolgoznak, azonban a technológia fejlödésének köszönhetően a fémes alapanyagból dolgozó eljárások pl. szelektív lézersugaras olvasztás (Selective Laser Melting - SLM), lézeres felrakó hegesztés (Laser Metal Deposition - LMD) és az alapanyagot jelentő fémporok tulajdonságainak fejlesztésével és ezek elterjedésével az ilyen módon elóállított termék nem prototípust, hanem végterméket jelent [1].

Ha a tervezés során figyelembe vesszük az additív gyártástechnológiát, akkor az optimalizálandó alkatrész geometriájának előállítása a hagyományos modellező eljárásokkal rendkívül időigényes müvelet. Ezeknek a megoldására jöttek létre a generatív tervező (generative design) szoftverek, illetve modulok.

\section{Alakoptimalizáció, topológiai optimalizáció}

A gépészeti tervezés folyamán végzett optimalizálás az adott müködési feltételek mellett kiválasztott legjobb megoldást jelenti, amit az előállított megoldások halmazából választunk ki. Matematikailag az optimalizálás egy célfüggvény maximumának vagy minimumának meghatározását jelenti. Általánosabban, az optimalizáció egy adott megengedett tartományon keresi egy célfüggvény legjobb értékét, ahol mind a megengedett tartomány, mind a célfüggvény különböző típusú lehet. Gyakran a tervezéskor definiált célfüggvény többcélú és többváltozós, így az optimalizálás inkább több célérték kiszámításaként definiálható.

Alakoptimalizáláskor az előállított testmodell határoló felületének alakját változtatjuk úgy, hogy a célfüggvény minél jobb értékéhez jussunk az optimálási feltételek betartásával. A CAD modell adatai tartalmazzák a tervezési változókat, a tervezési paramétereket, az anyagjellemzőket, valamint a végeselemes vizsgálatokhoz szükséges peremfeltételeket is. Alakoptimáláskor a tervezési változókat a geometriát leíró paraméterekből választjuk ki, ez a parametrikus adathalmaz (pl. méretek, alaksajátosságok, modell történet) automatikusan elóáll az alkalmazott parametrikus integrált tervezörendszerekben. Mivel egy alkatrész modelljét többféle módon is elöállíthatjuk (pl. alaksajátosságok megválasztása, müveletek sorrendje, vázlatok méretei), fontos megjegyezni, hogy ez hatással lehet az optimalizálási feladatra, így már a modellezéskor körültekintően kell a geometriát elöállítani.

Topológiai optimalizáláskor a cél, hogy meghatározzuk az alkatrész optimális kialakítását egy adott térfogaton belül, elöre definiált peremfeltételek és terhelések mellett. A topológiai optimalizálás során a kiinduló térfogat elemei törlődnek a tervezési térből a tervezési változók és a célfüggvény figyelembevételével. Az alakoptimáláskor rendelkezésre áll egy részletesen kidolgozott kezdeti geometria, míg a topológiai optimalizálásnál ez nem feltétlenül szükséges. Előfordulhatnak olyan elnevezések egyes szoftvereknél, amelyek alakoptimálásra utalnak, azonban az elöállított végeredmény egy topológiai optimalizáció eredménye. Az alak- és a topológiai optimalizáció közötti 
különbséget az alkalmazott eljárás teszi egyértelmüvé. A topológiai optimalizációs eljárások számításigényes numerikus és végeselemes algoritmusokat igényelnek, ezek elterjedése az elmúlt évtizedekben vált lehetővé. A gyakorlatban többféle módszert fejlesztettek ki, ezeket két nagy csoportba lehet besorolni:

1.) gradiens típusú módszerek:

- anyageloszlásos módszer: SIMP (Solid Isotrop Microstructure/Material with Penalties tömör izotróp mikroszerkezet/anyag büntetősúlyokkal) [2],

- homogenizáló módszerek OMP (Optimal Microstructure with Penalization - optimális mikroszerkezet büntetősúlyokkal), NOM (NonOptimal Microstructures - nem-optimális mikroszerkezet) [3],

- diszkrét, globális módszerek [4],

- topológiai derivált és szintvonalas módszer (LSM-Level Set Method) [5],

- hirtelen halál (Sudden Death Method) technikáját alkalmazó módszer, pl ESO (Evolutionary Structural Optimization - evolúciós szerkezet optimálás) [6];

2.) nem gradiens-típusú, heurisztikus módszerek [7].

Az egyik leghatékonyabb és a számítási igény szempontjából egyszerú módszer a SIMP módszer, a legtöbb szoftverfejlesztő ezt az eljárást alkalmazza a rendszereiben a topológiai optimalizáláshoz.

\section{A gépészeti generatív tervezési folyamat}

A generatív tervezést nem csak a gépészeti, hanem ezen kívül számos területen alkalmazhatják, pl. építészeti, bútoripari, mủvészeti alkotásoknál. A tervezés folyamata általánosítható, azonban a megközelítéskor a gépészeti tervezési folyamatokra összpontosítunk. Az additív és hibrid gyártástechnológia elterjedésének köszönhetően az utóbbi években egyre nagyobb hangsúlyt fektetnek a generatív tervezési módszerek megjelenésére a gépészeti tervező rendszerekben. A generatív tervezés egy újfajta tervezési folyamat, aminek a főbb jellemzői a mesterséges intelligencia alapú szoftver és gépi tanulás, aminek segítségével az alkatrész alakját és összetételét fizikai alapú szimulációs és egyéb elemzési módszerekkel határozza meg, figyelembe véve az elvárt követelményeket és optimalizálva a kitüzött célokat (pl. a minimális költség és/vagy tömeg). Ez az új tervezési folyamat abban különbözik a hagyományos módszerektől, hogy a generatív algoritmus kiértékeli és megváltoztatja a termék modelljét a következő elemzési iterációhoz felhasználói beavatkozás nélkül és jóval több megoldásváltozatot eredményez az adott funkcióra. A hagyományos tervezési folyamatnál további - felhasználó által vezérelt - iterációkra van szükség, míg eljutunk a gyártási folyamathoz, ez a termék bevezetési idejét növeli (1. ábra).

A generatív tervezési folyamatban a szoftver a gépi tanulás segítségével a természetre jellemző evolúciós megközelítést alkalmazza. A felhasználónak a tervezési változókat kell csak definiálni (pl. anyagokat, tervezői teret, tömeget, gyártástechnológiát, előállítási költséget). Ennek ismeretében a szoftver elöállítja a változók és paraméterek ismeretében az összes lehetséges kombinációt. A hagyományos tervezési folyamatokkal összehasonlítva az elöállított változatok száma nagyságrendekkel nagyobb lehet. Mivel a generált megoldásváltozatok mindegyike megfelel az elöírt gyárthatósági feltételeknek, így a halmazból kiválasztható az az egyed, ami a végleges megoldást jelenti (2. ábra). 


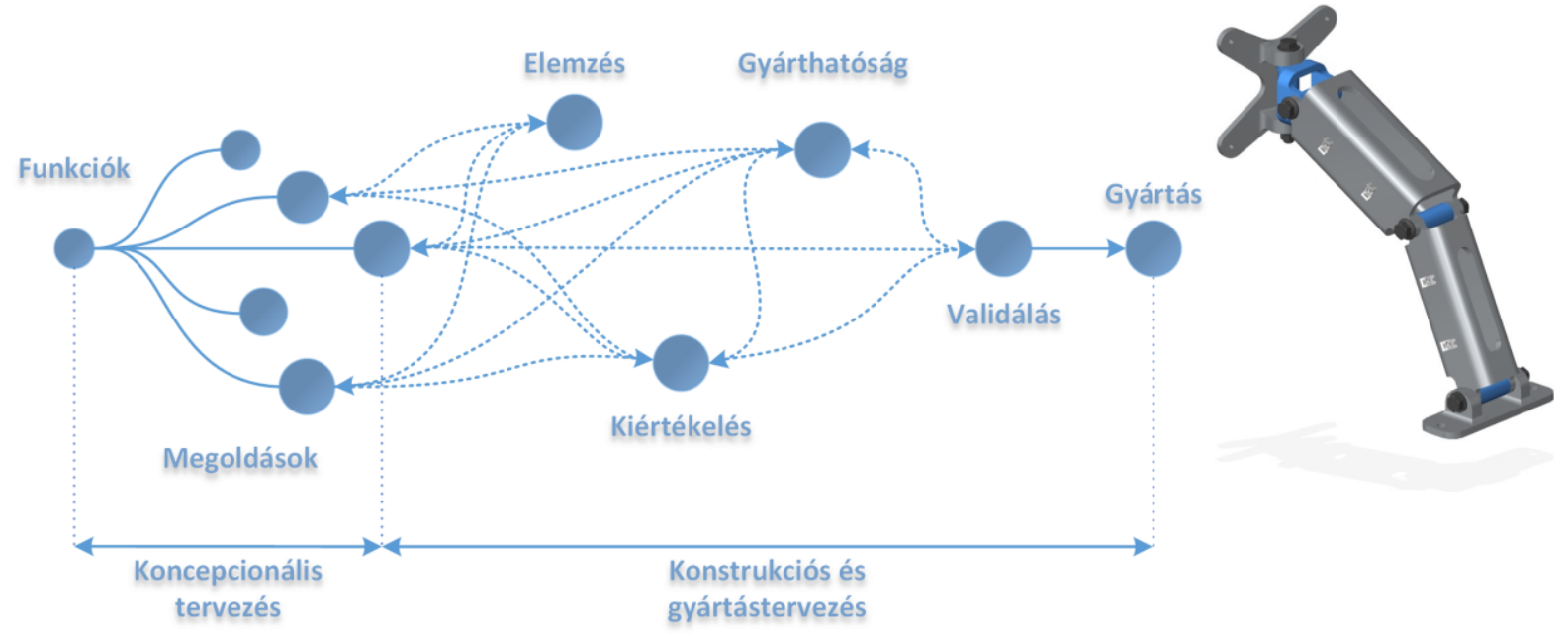

1. ábra. A hagyományos tervezési folyamat lépései
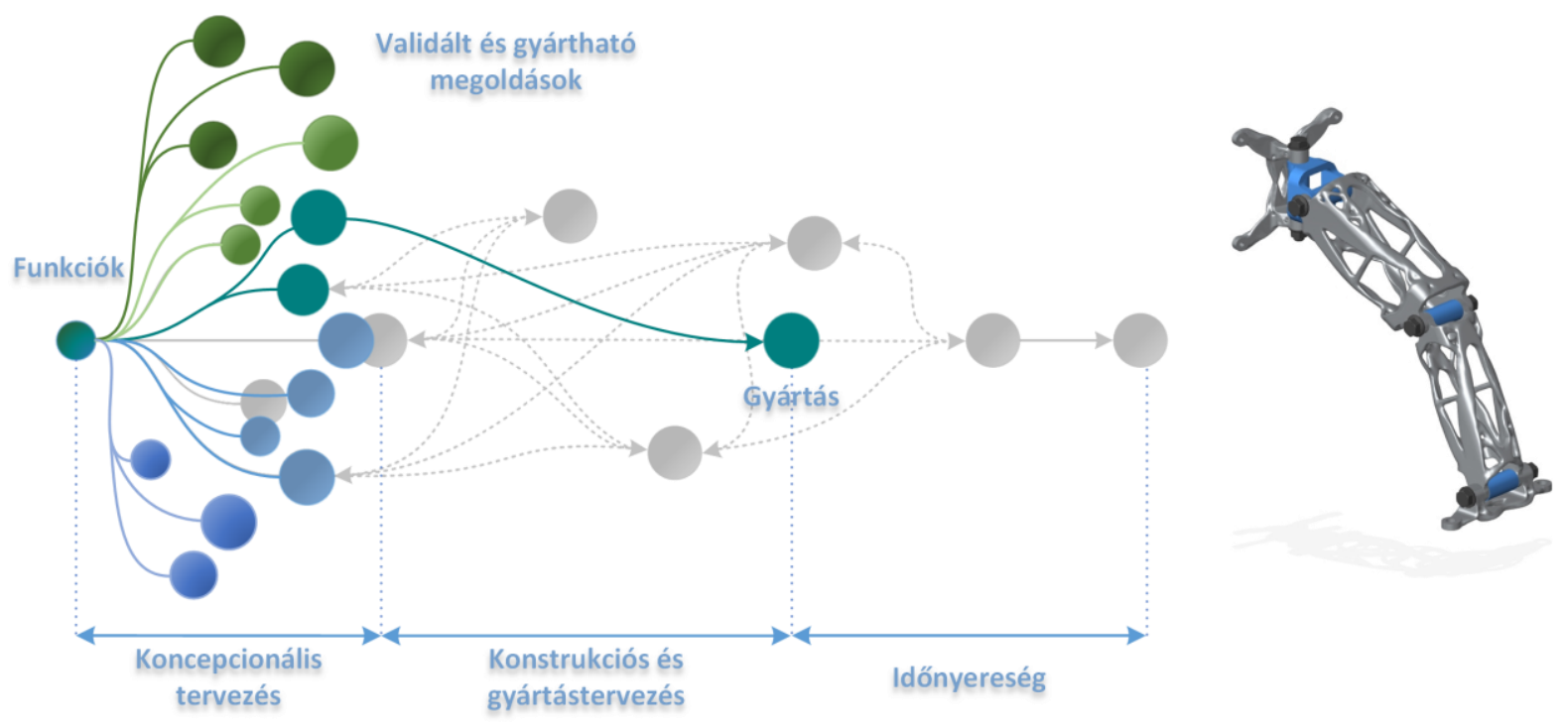

2. ábra. A generativ tervezési folyamat lépései

A generatív tervezés további jellemzője, hogy már a tervezési folyamat korai szakaszában is alkalmazható, anélkül, hogy meglévő koncepcionális terv állna rendelkezésre. Ennek köszönhetően a generatív algoritmus teljesen új megoldásokat hoz létre úgy, hogy számításba veszi a gyárthatósági szempontokat is, ezáltal jelentősen csökkenti az alkatrész tesztelési folyamatnak idejét. A hagyományos tervezési folyamatban az alak- vagy topológiai optimalizálás egy már előállított változatot céloz meg, ami a müködés szempontjából felesleges anyagot távolítja el, oly módon, hogy a gyárthatóságot és az elöállítási költségeket figyelmen kívül hagyja. Ennek következtében további modellezésre, hagyományos szimulációra és tesztelésre lehet szükség. A generatív tervezésnél a szimulációt a tervezési folyamatba integrálják. A generatív tervezési folyamatnál megadhatók tervezési változónak a gyártástechnológia jellemzői (pl. additív gyártás, 2,5-5D marást, öntés), így a 
szoftver csak olyan megoldásokat állít elő, amelyek megfelelnek a megadott változóknak. Az additív és hibrid megmunkálást figyelembe véve a generatív tervezéssel olyan több alkatrészből álló termékek is összevonhatók (funkció-összevonás) egy termékké, amelyek a hagyományos gyártástechnológia miatt ezt korábban nem tették lehetővé, ez a későbbi felhasználás szempontjából további költségmegtakarítást jelenthet pl. a beszállítói lánc tekintetében, vagy karbantartáskor, szereléskor.

\section{Példák generatív tervezést támogató szoftverekre}

A generatív tervezést támogató szoftverek a 2010-es évek első felében jelentek meg. Ezekben az években az Airbus részére fejlesztett az AutoDesk optimalizált szerkezeteket, ahol a fejlesztési részleg vezető mérnöke Jesse Coors-Blankenship volt. Az itt szerzett tapasztalatokat felhasználva alapította meg a Frustum nevü cégét, ahol kifejlesztette a TrueSOLID ${ }^{T M}$ néven futó generatív tervezést támogató kernelt, ez a termék több tervezőszoftverben is elérhető. A másik nagy fejlesztő az AutoDesk, ahol a kutatási részlegén futó Dreamcatcher nevü projektböl jött létre a generatív tervezést támogató termék, mely szintén elérhető. Felismerve a generatív tervezés igényét újabb szoftverfejlesztők termékei váltak elérhetővé. Ezek főbb jellemzői a széleskörü optimalizálást biztosító lehetőségek (pl. méret, tömeg, szilárdság, anyagminőség, költségek, ütemterv, gyárthatóság) valamint a felhő alapú szolgáltatás. A generatív tervezési folyamat iterációs eljárásaiban végzett számítási teljesítmény a hagyományos feladatokhoz viszonyítva jóval költségesebb, így a felhőalapú számítások költséghatékony hozzáférést biztosítanak a nagyszámú generált változatokhoz. Az 1. táblázat összefoglalja és röviden bemutatja a legismertebb generatív tervezést támogató termékeket.

1. táblázat. Generativ tervezöszoftverek [8]

\begin{tabular}{|l|l|l|}
\hline Szoftverfejlesztö & \multicolumn{1}{|c|}{ Termék } & \multicolumn{1}{c|}{ Jellemzők } \\
\hline Frustum & Generate & $\begin{array}{l}\text { Felhöalapú alkalmazás, a voxel-alapú tervezési algoritmust } \\
\text { egyesíti végeselemes analízissel. 2018 novemberéig önálló } \\
\text { termék, ezt követöen a PTC felvásárolta. }\end{array}$ \\
\hline nTopology & Element & $\begin{array}{l}\text { Generatív, függvényalapú alkalmazás, amely azonnali } \\
\text { visszajelzést ad a tervezés során, ahogy az objektum alakját, } \\
\text { valamint a gyártási folyamatot optimalizálja. }\end{array}$ \\
\hline ParaMatters & CogniCAD & $\begin{array}{l}\text { Felhöalapú tervezési platform, amely elsösorban az additív } \\
\text { gyártási folyamatokra fókuszál. }\end{array}$ \\
\hline
\end{tabular}

A mérnöki fejlesztést támogató szimulációs (pl. VEM, CFD) szoftverekben is elérhetők a topológiai optimalizálást és a generatív tervezést támogató eljárások (2. táblázat).

2. táblázat. Generatív tervezést támogató CAE szoftverek [8]

\begin{tabular}{|c|c|c|}
\hline Szoftverfejlesztö & Termék(ek) & Jellemzők \\
\hline Altair & OptiStruct & $\begin{array}{l}\text { Párhuzamos futtatást tesz lehetővé, hogy gyorsan } \\
\text { végrehaithassa a nagyméretủ optimalizálási feladatokat. }\end{array}$ \\
\hline ANSYS & $\begin{array}{l}\text { ANSYS } \\
\text { Mechanical }\end{array}$ & $\begin{array}{l}\text { Az ANSYS topológiai optimalizálási algoritmusa a } \\
\text { munkaasztalról indítható, így a szimulációs } \\
\text { munkafolyamatba illeszthető. }\end{array}$ \\
\hline $\begin{array}{l}\text { Dassault } \\
\text { Systèmes }\end{array}$ & $\begin{array}{l}\text { Tosca Structure, } \\
\text { Tosca Fluid }\end{array}$ & $\begin{array}{l}\text { A Tosca szerkezet optimalizáló csomag az ABAQUS, } \\
\text { ANSYS és MSC Nastran végeselemes megoldókkal } \\
\text { együttmüködve integrálódik a CAE környezetbe. }\end{array}$ \\
\hline
\end{tabular}




\begin{tabular}{|l|l|l|}
\hline ESI Group & $\begin{array}{l}\text { PAM-STAMP, } \\
\text { ProCAST, } \\
\text { SYSTUS }\end{array}$ & $\begin{array}{l}\text { Beépülő generatív tervezési technikákat kínál, valamint } \\
\text { speciális alakoptimalizálást a SYSTUS szimulációs } \\
\text { csomagban }\end{array}$ \\
\hline MSC Software & $\begin{array}{l}\text { MSC Nastran } \\
\text { Optimization }\end{array}$ & $\begin{array}{l}\text { Többféle eljárást kínál, az alak és topológiai optimalizálástól } \\
\text { a folyamatkezelési megoldásokig. }\end{array}$ \\
\hline
\end{tabular}

A generatív tervezést támogató modulok a parametrikus tervezőrendszerekben is elérhetők (3. táblázat). Ezek alapvetően a fent ismertetett fejlesztők termékei, melyek integrált módon érhetők el a rendszerekben.

3. táblázat. Integrált rendszerek generatív tervezö modullal [8]

\begin{tabular}{|c|c|c|}
\hline Szoftverfejlesztő & Termék(ek) & Jellemzők \\
\hline Autodesk & $\begin{array}{l}\text { Fusion } 360, \\
\text { Inventor }\end{array}$ & $\begin{array}{l}\text { A prémium elöfizetéseknél hozzáférést biztosít az } \\
\text { optimalizálási beállításokhoz és számításokhoz, valamint a } \\
\text { felhőalapú számítási erőforrásokhoz. }\end{array}$ \\
\hline $\begin{array}{l}\text { Dassault } \\
\text { Systèmes }\end{array}$ & TOSCA suite & $\begin{array}{l}\text { Hozzáférést biztosít a TOSCA optimalizáló csomaghoz a } \\
\text { CATIA és a SOLIDWORKS CAD szoftvereknél. }\end{array}$ \\
\hline $\begin{array}{l}\text { Robert McNeel } \\
\text { \& Associates }\end{array}$ & Rhino & $\begin{array}{l}\text { A Grasshopper vizuális programozási nyelvre és } \\
\text { környezetére támaszkodik a tervezés automatizálásához. A } \\
\text { felhasználók az alkatrészeket húzási múveletekkel, } \\
\text { logikailag összekapcsolják a tervnek megfelelően. }\end{array}$ \\
\hline PTC & Creo Simulate & $\begin{array}{l}\text { A Vanderplaats } \mathrm{K}+\mathrm{F} \text { GENESIS programot használja az } \\
\text { optimalizáláshoz. Az eredményeket szabadformájú (B-rep) } \\
\text { objektumokká konvertálja, így elkerülhetők a máshol } \\
\text { alkalmazott poligon modellek. A Creo } 7.0 \text { verziótól a } \\
\text { Frustum technológiáját használja }\end{array}$ \\
\hline Siemens & NX, Solid Edge & $\begin{array}{l}\text { A Frustum Generate kernelét integrálja a generatív } \\
\text { tervezéshez. A felhasználók a generált eredményeket } \\
\text { konvergens modellezéssel módosíthatják. }\end{array}$ \\
\hline Altair & $\begin{array}{l}\text { solidThinking } \\
\text { Inspire }\end{array}$ & $\begin{array}{l}\text { A topológiai optimalizáció a CAD modellezési folyamatba } \\
\text { integrált. }\end{array}$ \\
\hline
\end{tabular}

Az integrált rendszerekben elérhető modulok előnye, hogy a generatív tervezéssel elöállított modellek közvetlenül felhasználhatók az adott rendszerben, ́́gy nincs szükség a különböző szoftverek közötti termékadat cserére, ami konverziós hibákat okozhat.

\section{Esettanulmány generatív tervezésre}

A General Electric 2013. június 12-én egy versenykiírást tett közzé a grabcad közösségi felületen, mely alapján egy repülőgép-hajtómű tartóelemének optimalizálását kellett elvégezni additív gyártási technológiát feltételezve [9]. A kiírásban szereplő követelmények figyelembevételével és a rendelkezésre álló modell alapján a generatív tervezési módszer alkalmazásával előállítunk pár lehetséges megoldást az AutoDesk Fusion 360 és a Solid Edge 2020 szoftverekkel, aminek eredményeit ebben a fejezetben ismertetjük. 
A vizsgálandó alkatrész anyaga $T i-6 A l-4 V$, a feltételezett folyáshatár $R_{e}=131 \mathrm{ksi}$, az üzemi hőmérséklet $T_{s}=75 \mathrm{~F}$, a legkisebb falvastagság $t=0,05 i n$ (a mértékegységek megadásakor a kírásban szereplö értékeket alkalmaztuk). Az alkatrész elemzését négy terhelési esetre vizsgáljuk:

1.) a csapfelületen ébredő 8000lbs nagyságú terhelés az y tengellyel ellentétes irányban,

2.) a csapfelületen ébredő $8500 l b s$ nagyságú terhelés a $z$ tengellyel párhuzamos irányban,

3.) a csapfelületen ébredö 9500lbs nagyságú terhelés az yz síkban, $42^{\circ}$-os szöget bezárva az $F_{1}$ terheléssel,

4.) a csapfelület szimmetriatengelyének felezőpontján átmenő, $z$ tengellyel párhuzamos tengely körül ébredő 5000lb-in nagyságú csavarónyomaték (3. ábra).

A topológiai optimalizáláskor a célfüggvényt (minimális tömeg) adott biztonsági tényező $\left(n_{b}=2\right)$ mellett hajtottuk végre, az alkatrész eredeti tömege $m=2,038 \mathrm{~kg}$ volt.

$$
\begin{aligned}
& F_{1}=8000 \mathrm{lbs} \\
& F_{2}=8500 \mathrm{lbs} \\
& F_{3}=9500 \mathrm{lbs} \\
& T_{4}=5000 \mathrm{lb}-\mathrm{in}
\end{aligned}
$$
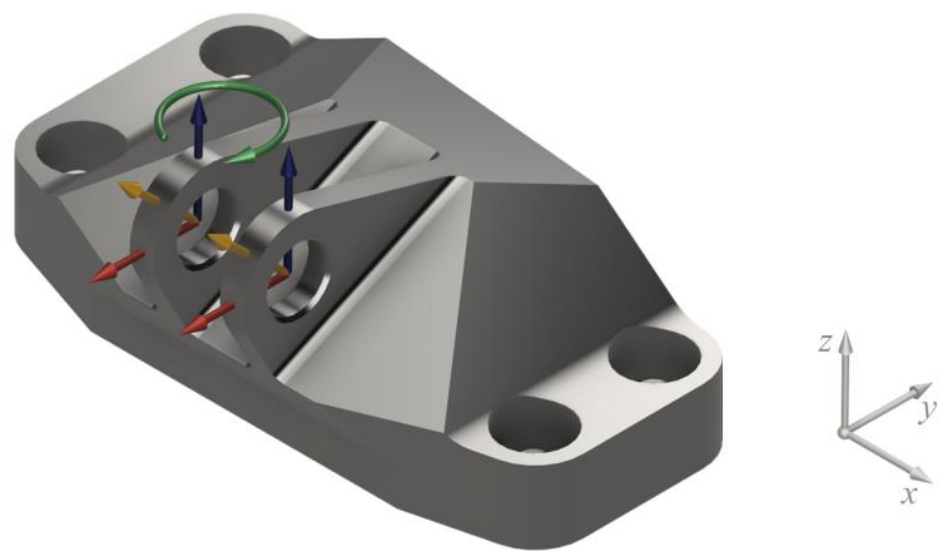

\section{3. ábra. A felfogató elem vizsgálandó terhelési esetei}

Az Autodesk Fusion 360 szoftver az additív gyártástechnológián kívül támogatja a marási $(2,5 D$ 5D) megmunkálással, 2 tengelyes megmunkálással, valamint az öntési technológiával elóállított termékek gyártására vonatkozó kritériumok beállítási lehetőségeit is. Ez a generált változatok számában jelent további megoldásokat. Az esettanulmányban a megmunkálási technológiáknál az $5 D$ $\mathrm{s}$ marást és az additív gyártást vettük figyelembe, ennek a szoftverben létrehozott táblázatos eredményeit a 4. ábra szemlélteti.

A generált megoldásváltozatok egymással összehasonlíthatók, így lehetőségünk van a kiválasztott végeredmények elemzésére, mely alapvetően az alkatrészen ébredő terheléseloszlást teszi lehetővé (5. ábra). Az ábrán megfigyelhető terheléseloszlások az ideális tartományban helyezkednek el, a rögzítő furatok némelyikénél az ébredő feszültségek nagysága alacsony értéket mutat, a gyakorlatban a terheléseloszlás megjelenítése ebben az esetben csak tájékoztató jellegü információt ad a felhasználónak, számszerü értékek meghatározását a generált modell végeselemes analízise teszi lehetővé. 


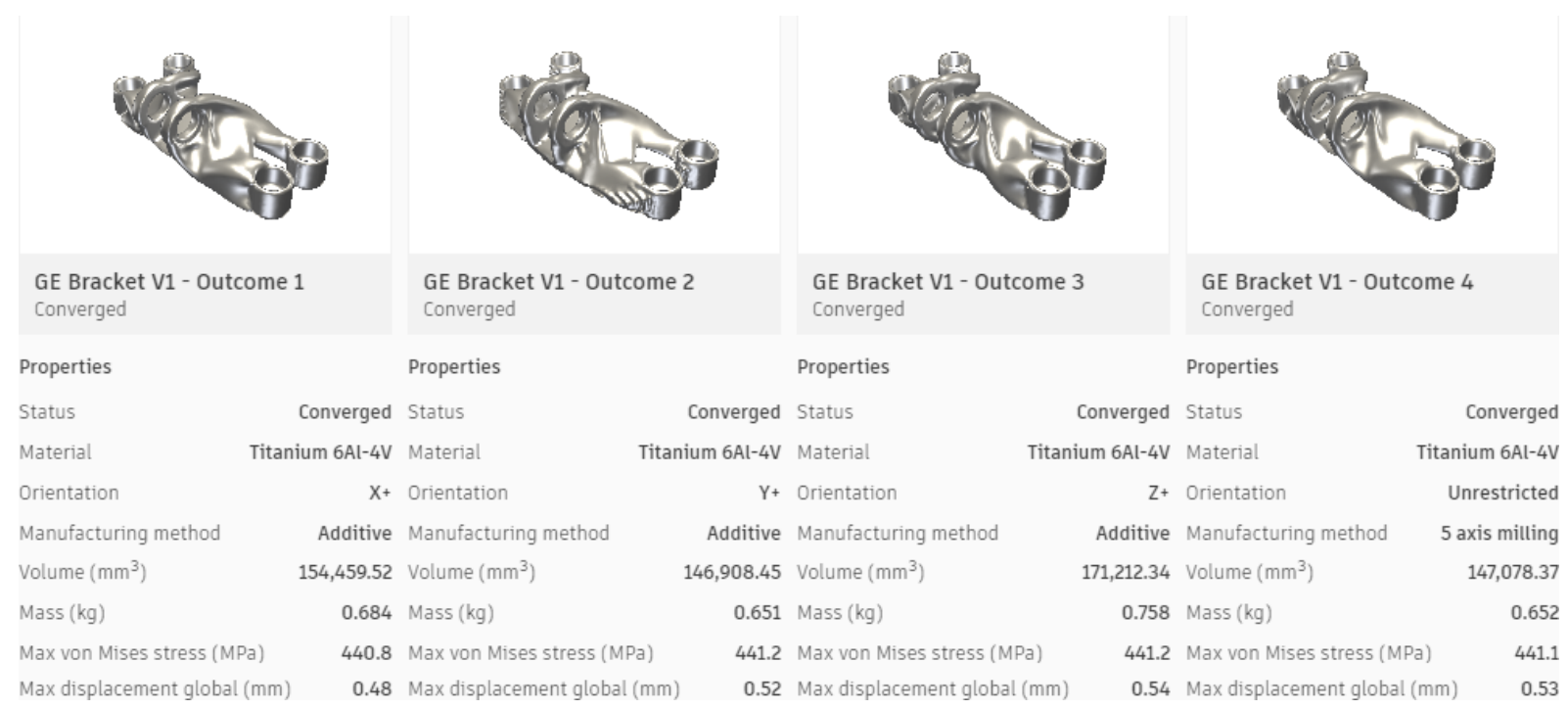

4. ábra. A generativ tervezés eredményei az AutoDesk Fusion 360 szoftverrel

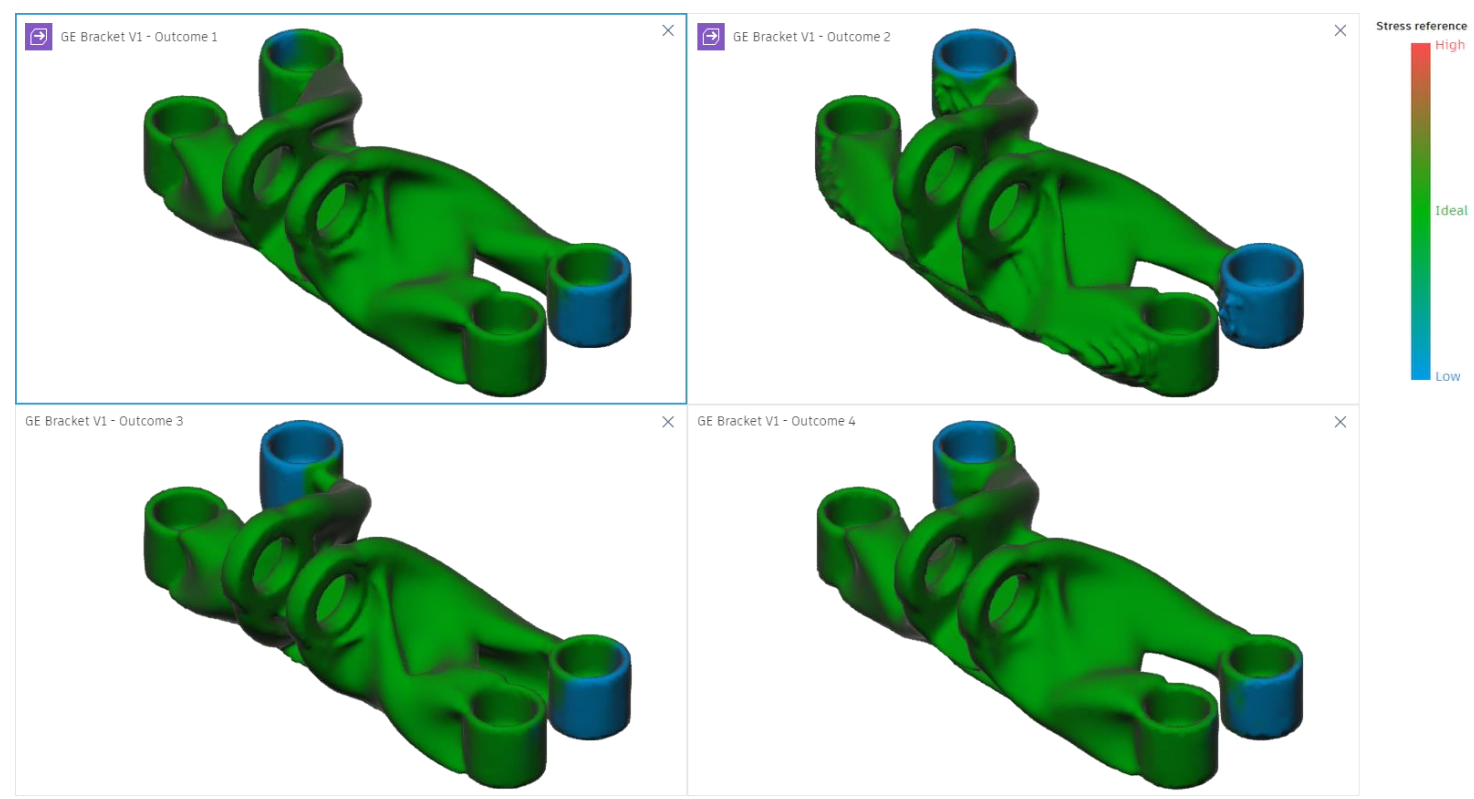

5. ábra. Generált változatok terheléseloszlásának eredményei az AutoDesk Fusion 360 szoftverben

A Solid Edge 2020 Premium változata lehetőséget ad a generatív tervezési folyamatok végrehajtására, azonban a szolgáltatások korlátozottabbak, továbbá a müveletek végrehajtása nagyobb felhasználói beavatkozást igényel, emiatt az több időt is vesz igénybe. A gyártási eljárásoknál választható az additív, valamint a hagyományos (pl. öntés, esztergálás) megmunkálás, azonban egy vizsgálatban több megmunkálási mód megadására nincs lehetőség. 
4. táblázat. A generatív tervezés eredményei az Solid Edge 2020 Premium szoftverrel

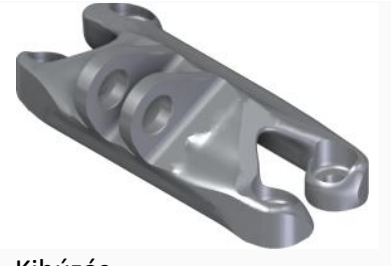

Kihúzás

Gyártás

Térfogat $\left(\mathrm{mm}^{3}\right)$

Tömeg (kg)
Additív

241533

1,088

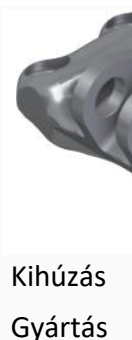

Térfogat

Tömeg

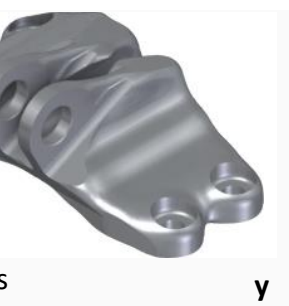

Addití

304,937

1,374

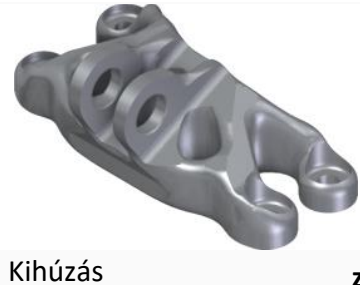

Gyártás

Térfogat

Tömeg

198,612

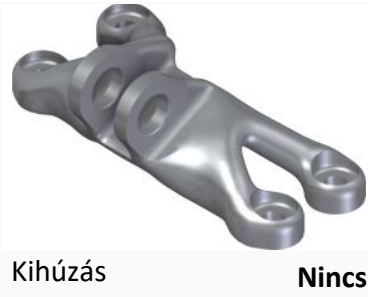

Additív Gyártás

Additív

Térfogat $\left(\mathrm{mm}^{3}\right)$

126785

0,894 Tömeg

Amennyiben többféle gyártási módot szeretnénk vizsgálni, újabb generatív vizsgálatokat kell létrehoznia a felhasználónak (4. táblázat). Amennyiben a generált változatok rendelkezésre állnak, ezek összehasonlítása is lehetővé válik. A különböző változatok terheléseloszlásának eredményeit a 6 . ábra szemlélteti.

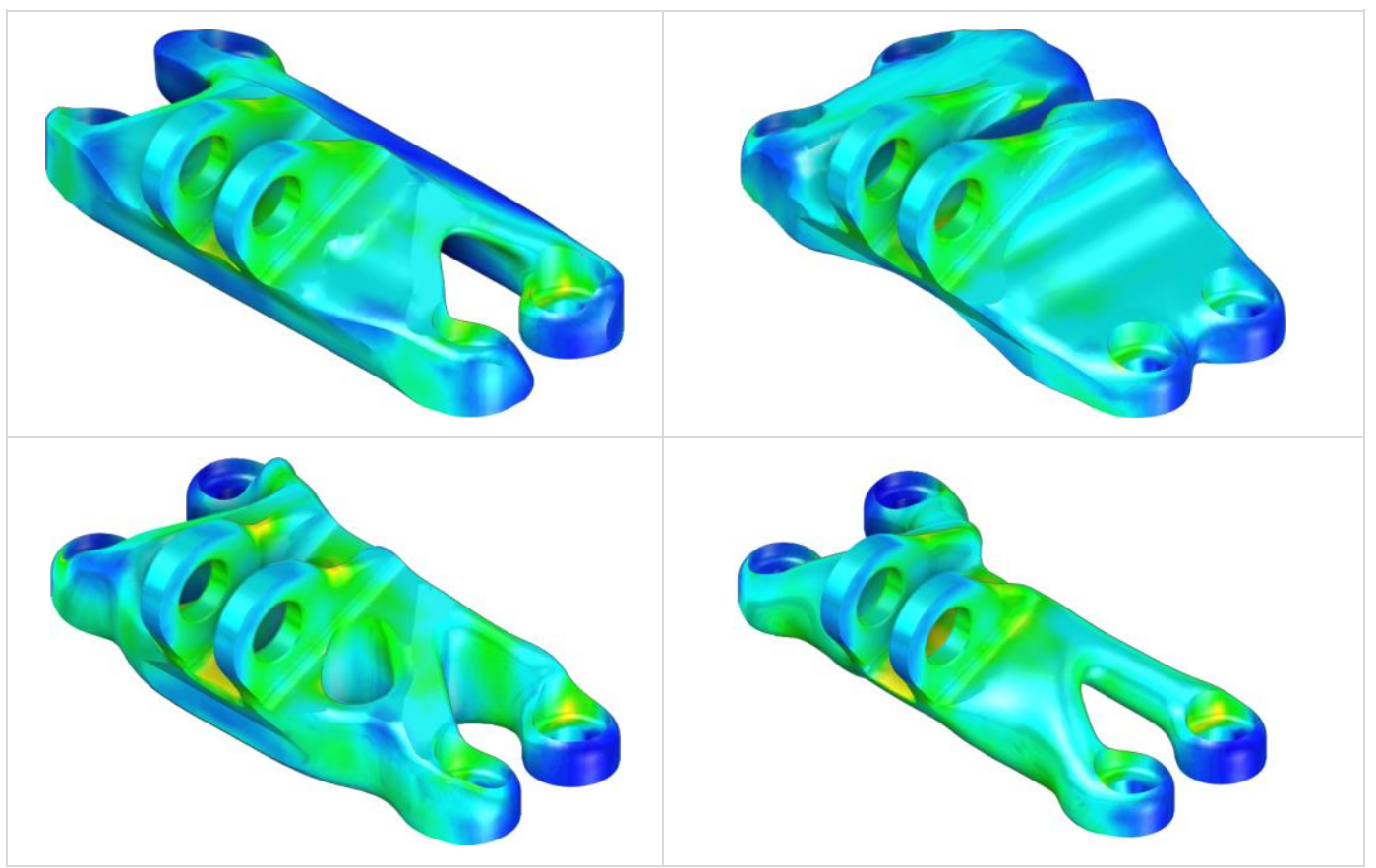

6. ábra. Generált változatok terheléseloszlásának eredményei a Solid Edge 2020 Premium szoftverben

A terheléseloszlás számszerü értékeinek vizsgálatára nincs lehetőség, hasonlóan az AutoDesk Fusion 360 szoftverhez. A kapott eredmények csak tájékoztató jellegűek, amik lehetővé teszik a terhelés szempontjából kritikus régiók azonosítását, azonban egyértelmüen látható, hogy a terheléseloszlás nem ideális, ahogy azt korábban az 5. ábra szemléltette. Hátrányként említhető, hogy a szoftver az eredmények táblázatos megjelenítését és a generált változatok egyidejü vizuális összehasonlítását nem teszi lehetővé, valamint a jellemző geometriai adatok (pl. térfogat), a maximális von Mises feszültség és a globális elmozdulás számszerü értékeiről még tájékoztató adat sem áll a 
felhasználó rendelkezésére. A két szoftver eredményeit összehasonlítva látható, hogy hasonló beállítási paraméterek mellett is eltérő megoldásokat kapunk.

\section{6. Összefoglalás}

Jelen cikkben röviden áttekintettük a generatív tervezési folyamatot támogató különböző szoftver alkalmazásokat. A gépészeti tervezőrendszerekben elterjedt generatív modult fejlesztő két nagy cég (AutoDesk, Frustum) megoldásait egy esettanulmányon keresztül megvizsgáltuk. Összehasonlítva a két generatív tervező modult kijelenthetö, hogy az AutoDesk Fusion 360 szoftverben alkalmazott felhőalapú technológia a generatív tervezési folyamat idejét lerövidíti, valamint a generálható megoldások számát a beállítható megmunkálási paraméterek egy adott vizsgálaton belül jelentősen növelhetik (egy vizsgálat - sok megoldás). A Solid Edge 2020 Premium szoftverbe integrált Frustum Generate generatív modul fö jellemzője, hogy az az adott gépen futtatható, így a generált modellekhez szükséges számítási kapacitást a felhasználó számítógépe korlátozza. További jellemző hátránya, hogy a vizsgálatokban egyidejüleg csak egy megmunkálási mód adható meg, ami csökkenti a generálható megoldások számát egy vizsgálaton belül. Amennyiben többféle megoldásváltozatot szeretnénk létrehozni, többféle vizsgálatot kell futtatni (sok megoldás - sok vizsgálat), ami a tervezési folyamat idejét növeli.

\section{Köszönetnyilvánítás}

A cikkben ismertetett kutató munka az EFOP-3.6.1-16-2016-00011 jelü „Fiatalodó és Megújuló Egyetem - Innovatív Tudásváros - a Miskolci Egyetem intelligens szakosodást szolgáló intézményi fejlesztése" projekt részeként - a Széchenyi 2020 keretében - az Európai Unió támogatásával, az Európai Szociális Alap társfinanszírozásával valósul meg.

\section{Irodalom}

[1] Gibson, I., Rosen, D., Stucker, B.: Additive manufacturing technologies. Springer, New York, 2010, ISBN 978-1-4419-1119-3 https://doi.org/10.1007/978-1-4419-1120-9

[2] Zuo, K., Chen, L., Zhang, Y., Yang, J.: Study of key algorithms in topology optimization, Int J Adv Manuf Technol 32, 787-796 (2007) https://doi.org/10.1007/s00170-005-0387-0

[3] Rozvany, G.: Aims, scope, methods, history and unified terminology of computer-aided topology optimization in structural mechanics, Struct Multidisc Optim 21, 90-108 (2001) https://doi.org/10.1007/s001580050174

[4] Bendsøe, M.: Optimization Of Structural Topology, Shape, And Material, Springer, Berlin, 1995, ISBN 978-3-662-03117-9 https://doi.org/10.1007/978-3-662-03115-5

[5] Novotny, A., Sokolowski, J.: Topological Derivative In Shape Optimization, Springer, Berlin, 2013, ISBN 978-3-642-35244-7 https://doi.org/10.1007/978-3-642-35245-4

[6] Huang, X., Xie, Y.: Evolutionary Topology Optimization Of Continuum Structures, Wiley, Chichester, 2010, ISBN 978-0-470-74653-0

[7] Tajs-Zielińska, K., Bochenek, B.: A heuristic approach to optimization of structural topology including self-weight, AIP Conference Proceedings 1922, 020001 (2018) https://doi.org/10.1063/1.5019028

[8] An Introduction to Generative Design - A Digital Guide from the Editors of Cadalyst, Cadalyst, Longitude Media, 2018, https://cadalyst.tradepub.com/free/w_cada04/prgm.cgi

[9] https://grabcad.com/challenges/ge-jet-engine-bracket-challenge 